\title{
Mechanisms for the Mutarotation and Hydrolysis of the Glycosylamines and the Mutarotation of the Sugars
}

\author{
Horace S. Isbell and Harriet L. Frush
}

\begin{abstract}
A study has been made of the kinetics of the mutarotation and hydrolysis reactions of $\mathrm{L}$-arabinosylamine, and a mechanism has been devised to account for the striking sensitivity of the glycosylamines to hydrolysis in a limited $\mathrm{pH}$ range. The concepts presented seem applicable for the interpretation of the reactions of other compounds of the aldehyde ammonia type.
\end{abstract}

\section{Introduction}

In the development of methods for the preparation of the amides of uronic acids [1] ${ }^{1}$ it became necessary to determine conditions whereby the amino group of a 1-amino-uronic amide could be hydrolyzed without alteration of the amide group. It was found that the rate of hydrolysis of the amino group of 1-aminomannuronic amide (I) is extraordinarily sensitive to the acidity of the reaction medium. Thus, when the compound is mixed quickly with one equivalent of a strong acid, hydrolysis requires a period of many hours, but when the acid is added dropwise to the compound in solution, hydrolysis is complete in $15 \mathrm{~min}$ or less. Further study showed that 1-aminomannuronic amide is surprisingly stable both to strong acid and to alkali, and that hydrolysis can be effected rapidly only in the $\mathrm{pH}$ range 4 to 7 . Because of the presence of the hydrolyzable amide group in 1-aminomannuronic amide, the study of the hydrolysis was directed to the 1-aminosugars, more properly designated glycosylamines.

Exploratory experiments with glucosylamine, galactosylamine, and arabinosylamine showed that the glycosylamines in general possess the peculiar sensitivity to hydrolysis in a limited $\mathrm{pH}$ range that had been noted for 1-aminomannuronic amide [2]. In this paper, the mutarotation and hydrolysis of L-arabinosylamine are considered in detail. Mechanisms for the mutarotation of the sugars, comparable to those for the mutarotation of the glycosylamines, correlate the properties of the two groups of substances and account for the over-all rate of mutarotation of both the glycosylamines and the sugars as a function of $\mathrm{pH}$.

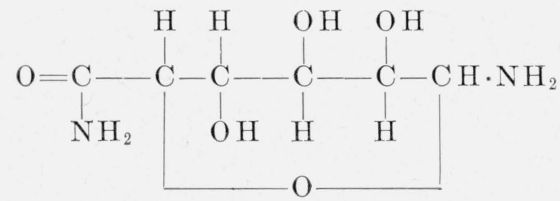

1-Aminomannuronic amide

\footnotetext{
1 Figures in brackets indicate the literature references at the end of this paper.
}<smiles>CC(N)C(O)C(O)C(C)O</smiles>

L-Arabinosylamine<smiles>CCC(C)C(OC)C(OC)C(C)OC</smiles>

III.

Tetraacetyl-L-arabinosylamine<smiles>CCC(C)C(O)C(O)CO</smiles>

IV.

$N$-Acetyl-L-arabinosylamine

\section{Structure and Chemical Properties of L-Arabinosylamine}

L-arabinosylamine (II) was prepared by treating L-arabinose in methanol with ammonia essentially by the method of de Bruyn and Van Leent [3]. Acetylation of the compound with acetic anhydride and pyridine yielded a new tetraacetate (III). Catalytic deacetylation of this substance with barium methylate in methanol gave a crystalline $N$-acetyl-Larabinosylamine. ${ }^{2}$ The latter substance was found to react quickly with 2 moles of sodium periodate, as required for an $N$-acetylpentosylamine having the pyranose structure IV. Since acetylation and deacetylation were carried out by mild reactions that ordinarily cause no change in ring structure, the original L-arabinosylamine and its tetraacetate are tentatively classified as pyranoses.

In a slow titration of L-arabinosylamine, one equivalent of acid was required for neutralization

${ }_{2}^{2}$ This compound is analogous to the $N$-acetyl-D-glucosylamine prepared by Brigl and Keppler [4] and shown by Niemann and Hays [5] to be a pyranose. 


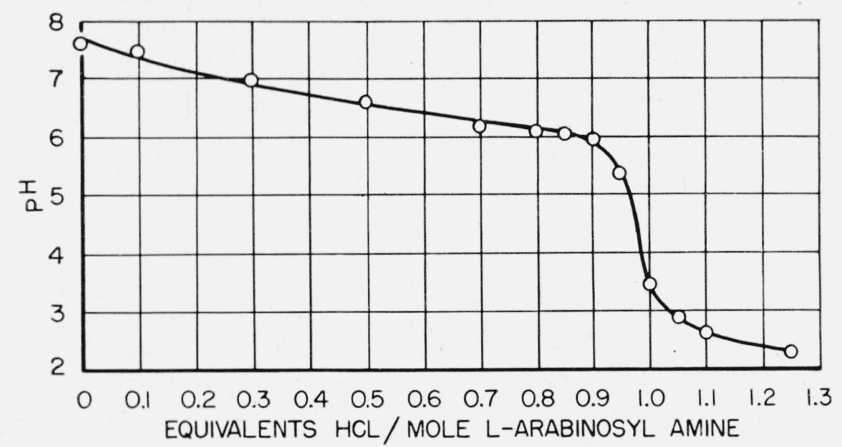

Figure 1. Titration of L-arabinosylamine with acid.

(fig. 1). Separation of crystalline L-arabinose in nearly quantitative yield from the mixture after titration established the fact that this treatment with dilute acid had caused hydrolysis of the glycosylamine and formation of the free sugar.

When dissolved in water, L-arabinosylamine undergoes spontaneous changes that give rise to a decrease in optical rotation and then to an increase. The changes can be ascribed principally to a mutarotation reaction that establishes equilibrium between the various modifications of the glycosylamine, and hydrolysis of the amino group. ${ }^{3}$ The relative rates of the two reactions vary with experimental conditions (fig. 2). Thus, when L-arabinosylamine is dissolved in strong acid, the optical rotation drops almost at once to about $+69^{\circ}$, and then increases slowly over a period of several weeks (curve I). However, if it is dissolved in weak acid, for example in water saturated with carbon dioxide, the optical rotation drops immediately to about $+70^{\circ}$ and then increases rapidly to $+105^{\circ}$ (curve II). In a weakly alkaline solution prepared by dissolving the substance in carbon dioxide-free water, the specific rotation decreases in the course of a few hours from $+86^{\circ}$ to a minimum, and then slowly rises (curve III). In strong alkali there is almost no change (curve IV).

These qualitative observations may be summarized as follows:

\begin{tabular}{|c|c|c|}
\hline Solution & $\begin{array}{l}\text { Mutarotation } \\
\text { reaction }\end{array}$ & Hydrolysis reaction \\
\hline $\begin{array}{l}\text { Strongly acid } \\
\text { Weakly acid } \\
\text { Weakly alkaline } \\
\text { Strongly alkaline_. }\end{array}$ & $\begin{array}{l}\text { Very rapid } \\
\text { Rapid, but meas- } \\
\text { urable. } \\
\text { Slow }\end{array}$ & $\begin{array}{l}\text { Slow. } \\
\text { Rapid, but meas- } \\
\text { urable. } \\
\text { Slow. } \\
\text { Do. }\end{array}$ \\
\hline
\end{tabular}

To obtain quantitative data as to the effect of the oxonium ion concentration, samples of L-arabinosyl-

3 The process appears to be complicated under some conditions by the formation of the diglycosylamine, and possibly by other reactions that depend on the presence of an intermediate imine cation. See page 142. amine were treated with acids and bases in solutions buffered at various $\mathrm{pH}$ values, and the ensuing reactions were followed by optical rotation. Although the mutarotation and hydrolysis reactions of L-arabinosylamine take place simultaneously, they can be studied separately because their rates at a given $\mathrm{pH}$ value differ widely, and because the change in optical rotation accompanying each of the two reactions is large. For study, the change in optical rotation was considered to consist of two periods: a short period beginning at zero time and characterized by a decrease in dextrorotation; and a long period beginning when the initial change was complete, characterized by an increase in dextrorotation and extending until the optical rotation reached a value corresponding to complete hydrolysis $\left(+105.2^{\circ}\right)$. The rate of the mutarotation reaction was obtained from the data for the first period and the rate of the hydrolysis reaction from the data for the second period. Suitable data were obtained for the mutarotation reaction in alkaline solutions, in which the hydrolysis is extremely slow, and for the hydrolysis reaction in weakly alkaline or acid solutions, in which the mutarotation reaction is almost instantaneous.

Satisfactory rate constants for the mutarotation of $\mathrm{L}$-arabinosylamine were obtained in the $\mathrm{pH}$ range 7.8 to 12 by application of the customary formula ${ }^{4}$ for a first-order reaction to the data of table 1 . Table 2 gives the mutarotation constants that were obtained for a series of experiments used to evaluate the catalytic effects of the oxonium, hydroxyl, and ammonium ions. The dotted curve of figure 3 represents these mutarotation constants corrected for the catalytic effect of the ammonium ion. The results clearly show that the mutarotation of L-arabinosylamine is strongly catalyzed by acids but not appreciably by bases. ${ }^{5}$ The mutarotation differs from

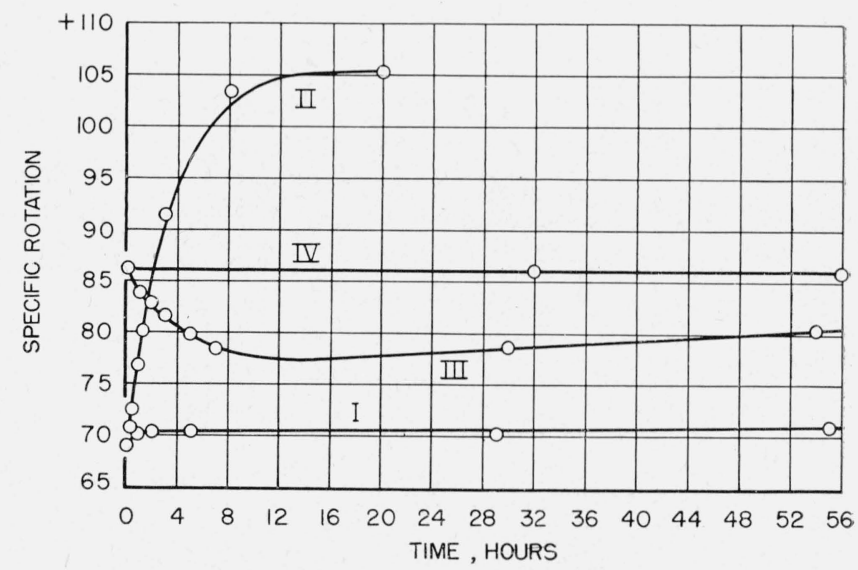

Figure 2. Mutarotation of L-arabionsylamine.

I, In $2.5 \mathrm{~N} \mathrm{HCl}$; II, in $\mathrm{CO}_{2}$-saturated water; III, in $\mathrm{CO}_{2}$-free water; $\mathrm{IV}$, in $0.0 \mathrm{I}$ $\mathrm{N} \mathrm{NaOH}$.

${ }^{4}$ The first-order formula is applicable if the concentrations of the acid and base catalysts are held constant.

5 However, unpublished work has shown that the mutarotation of $\alpha$-D-galacto sylamine is weakly but definitely catalyzed by bases. 
the mutarotations of the sugars in that the latter are catalyzed by bases more strongly than by acids. The reason for this difference will be considered in the next section.

TABLE 1. Mutarotation and hydrolysis measurements

$0.5 \mathrm{~g}$ of L-arabinosylamine dissolved in sufficient acid, base, or buffer to give a volume of $25 \mathrm{ml}$. Solvents are listed opposite experiment numbers.

\begin{tabular}{|c|c|c|c|c|}
\hline $\begin{array}{c}\text { Time } \\
\text { (minutes) }\end{array}$ & {$[\alpha]_{D}^{20}$} & $\mathrm{pH}$ & $\begin{array}{l}\text { Mutarotation con- } \\
\text { stant, } \mathrm{a} \\
k_{m}=\frac{1}{t_{2}-t_{1}} \log \frac{r_{t_{1}}-r_{m}}{r_{t_{2}}-r_{m}}\end{array}$ & $\begin{array}{l}\text { Hydrolysis rate } \\
\text { constant, }{ }^{a} k_{\text {hy drol }} \\
=\frac{1}{t_{2}-t_{1}} \log \frac{r_{t_{1}}-r_{\infty}}{r_{t_{2}}-r_{\infty}}\end{array}$ \\
\hline \multicolumn{5}{|c|}{ Experiment $1.0 .01 \mathrm{~N} \mathrm{NaOH}$} \\
\hline \multirow[t]{2}{*}{$\begin{array}{r}10 \\
32 \\
60 \\
120 \\
270 \\
1.250 \\
\end{array}$} & \multirow[t]{2}{*}{$\begin{array}{r}+86.4 \\
86.1 \\
86.0 \\
85.1 \\
82.7 \\
77.6 \\
\text { b }(69.0)\end{array}$} & $\begin{array}{l}\cdots \\
\cdots \\
\cdots \\
\cdots\end{array}$ & $\begin{array}{c}0.00034 \\
.00040 \\
.00031 \\
.00040 \\
\end{array}$ & \multirow[t]{2}{*}{ - } \\
\hline & & Avg & 0.00036 & \\
\hline
\end{tabular}

Experiment 2. $0.1 \mathrm{~N} \mathrm{HCl}+\mathrm{NH}_{3}$ to $\mathrm{pH} 10.5$

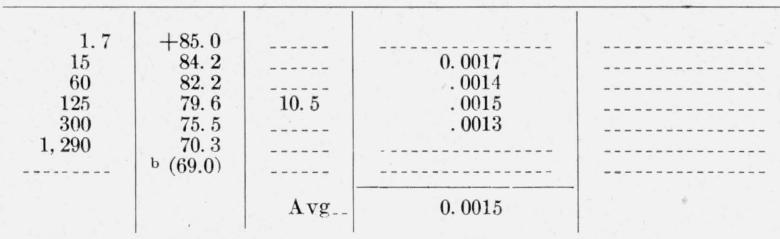

Experiment 3. $2.5 \mathrm{~N} \mathrm{HCl}+\mathrm{NH}_{3}$ to $\mathrm{pH} 10.5$

\begin{tabular}{|c|c|c|c|c|}
\hline \multirow[t]{2}{*}{$\begin{array}{r}3.3 \\
4.9 \\
10.2 \\
20.1 \\
30.2 \\
120.0\end{array}$} & \multirow[t]{2}{*}{$\begin{array}{r}+78.7 \\
77.2 \\
73.1 \\
67.7 \\
65.3 \\
\text { c }(61.9)\end{array}$} & $\begin{array}{l}-\cdots \\
\cdots \\
\cdots \\
\cdots\end{array}$ & $\begin{array}{r}0.025 \\
.026 \\
.027 \\
.026 \\
\end{array}$ & \multirow[t]{2}{*}{$\begin{array}{c}-1 \\
-1\end{array}$} \\
\hline & & Arg & 0.026 & \\
\hline
\end{tabular}

Experiment 4. $0.1 \mathrm{~N} \mathrm{HCl}+\mathrm{NH}_{3}$ to $\mathrm{pH} 8.0$

\begin{tabular}{|c|c|c|c|c|}
\hline \multirow[t]{2}{*}{$\begin{array}{r}2.2 \\
6.1 \\
12.1 \\
21.1 \\
145\end{array}$} & \multirow[t]{2}{*}{$\begin{array}{r}+82.2 \\
79.2 \\
76.0 \\
73.2 \\
66.9\end{array}$} & 8.5 & $\begin{array}{r}0.024 \\
.023 \\
.019\end{array}$ & \multirow[t]{2}{*}{ - } \\
\hline & & $A v$ & 0.022 & \\
\hline
\end{tabular}

Experiment 5. $1 \mathrm{~N} \mathrm{HCl}+\mathrm{NH}_{3}$ to $\mathrm{pH} 8.0$

\begin{tabular}{|c|c|c|c|c|}
\hline \multirow[t]{2}{*}{$\begin{array}{r}1.6 \\
6.5 \\
8.7 \\
17.0 \\
30.2\end{array}$} & \multirow[t]{2}{*}{$\begin{array}{r}+81.5 \\
75.6 \\
74.0 \\
70.7 \\
69.0\end{array}$} & 8.2 & $\begin{array}{r}0.057 \\
.056 \\
.056 \\
\end{array}$ & \\
\hline & & Avg & 0.056 & \\
\hline
\end{tabular}

Experiment 6. $1 \mathrm{~N} \mathrm{HCl}+\mathrm{NH}_{3}$ to $\mathrm{pH} 7.5$

\begin{tabular}{|c|c|c|c|c|}
\hline \multirow[t]{2}{*}{$\begin{array}{r}1.9 \\
3.8 \\
4.8 \\
61.9 \\
21.8\end{array}$} & \multirow[t]{2}{*}{$\begin{array}{r}+78.2 \\
74.5 \\
73.2 \\
71.3 \\
68.9\end{array}$} & 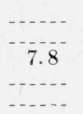 & $\begin{array}{r}0.116 \\
.116 \\
.118 \\
\end{array}$ & $\begin{array}{l}-\cdots \\
\cdots \\
\cdots \\
\cdots \\
-\cdots\end{array}$ \\
\hline & & $\mathrm{Avg}_{2}$ & 0.117 & \\
\hline
\end{tabular}

TABLE 1. Mutarotation and hydrolysis measurements-Con. $0.5 \mathrm{~g}$ of L-arabinosylamine dissolved in sufficient acid, base, or buffer to give a volume of $25 \mathrm{ml}$. Solvents are listed opposite experiment numbers.

\begin{tabular}{|c|c|c|c|c|}
\hline Time & & & $\begin{array}{l}\text { Mutarotation con- } \\
\text { stant, a }\end{array}$ & $\begin{array}{l}\text { Hydrolysis rate } \\
\text { constant, a } k_{\mathrm{h} y d r o l}\end{array}$ \\
\hline (minutes) & {$[\alpha]_{D}$} & $\mathrm{pH}$ & $k_{m}=\frac{1}{t_{2}-t_{1}} \log \frac{r_{t_{1}}-r_{m}}{r_{t_{2}}-r_{m}}$ & $=\frac{1}{t_{2}-t_{1}} \log \frac{r_{t_{1}}-r_{\infty}}{r_{t_{2}}-r_{\infty}}$ \\
\hline
\end{tabular}

Experiment 7.1 volume of $1 \mathrm{M} \mathrm{KH}_{2} \mathrm{PO}_{4}+1$ volume of $1 \mathrm{~N} \mathrm{NaOH}, \mathrm{pH} 10.0$

\begin{tabular}{|c|c|c|c|c|}
\hline 2. 7 & +82.4 & -- & & \\
\hline 4. 3 & 81.5 & & 0.019 & \\
\hline 6.0 & 80.4 & 10.0 & .021 & $\ldots$ \\
\hline 12. 8 & 76.4 & ....... & .026 & $\ldots$ \\
\hline 17.1 & 74.7 & ...... & .025 &.- \\
\hline 60.0 & $\begin{array}{c}70.3 \\
\text { b }(69.0)\end{array}$ & -..... & - & \\
\hline \multirow{6}{*}{$\begin{array}{c}210.0 \\
1,750 \\
3.570 \\
4,560 \\
\infty\end{array}$} & \multirow{6}{*}{$\begin{array}{r}+72.2 \\
81.6 \\
84.6 \\
85.1 \\
\text { d (105.2) }\end{array}$} & A vg .- & 0.023 & \multirow{5}{*}{$\begin{array}{r}0.00009 \\
.00006 \\
.00005\end{array}$} \\
\hline & & $\ldots$ & - & \\
\hline & & ....... & ... & \\
\hline & & ...... & - & \\
\hline & & 104 & -... & \\
\hline & & & Avg.. & 0.00007 \\
\hline
\end{tabular}

Experiment 8.1 volume of $1 \mathrm{~N} \mathrm{Na}_{2} \mathrm{CO}_{3}+1$ volume of $1 \mathrm{~N} \mathrm{NaHCO}_{3}, \mathrm{pH} 9.4$

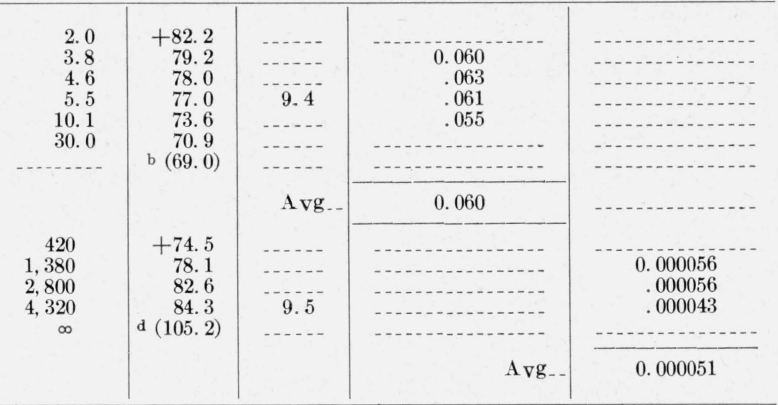

Experiment 9.1 volume of $1 \mathrm{~N} \mathrm{Na}_{2} \mathrm{CO}_{3}+10$ volumes of $1 \mathrm{~N} \mathrm{NaHCO}, \mathrm{pH} 8.6$

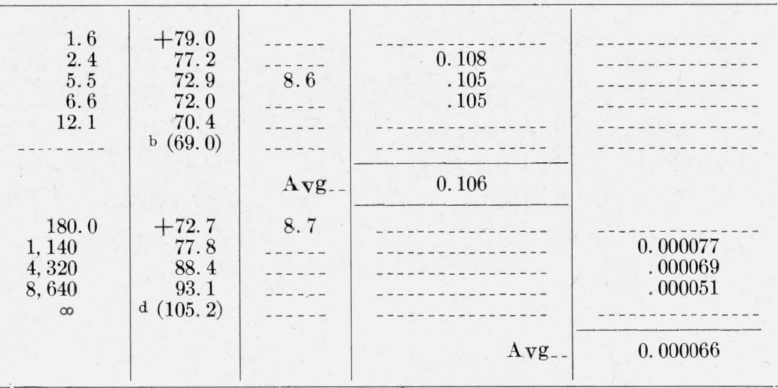

Experiment 10. 10 volumes of $1 \mathrm{M} \mathrm{KH}_{2} \mathrm{PO}_{4}+7$ volumes of $1 \mathrm{~N} \mathrm{NaOH}$ diluted to 20 volumes, $\mathrm{pH} 7.0$

\begin{tabular}{|c|c|c|c|c|}
\hline $\begin{array}{r}1.4 \\
6.0 \\
10.5 \\
20.4 \\
1500 .\end{array}$ & $\begin{array}{r}+71.3 \\
78.1 \\
81.5 \\
87.6 \\
103.1\end{array}$ & 7.2 & 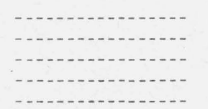 & $\begin{array}{l}0.023 \\
.018 \\
.016 \\
\end{array}$ \\
\hline & & & Avg... & 0.019 \\
\hline
\end{tabular}

Experiment 11. 2 volumes of $1 M \mathrm{KH}_{2} \mathrm{PO}_{4}+1$ volume of $1 \mathrm{~N} \mathrm{NaOH}$ diluted to 4 volumes, $\mathrm{pH} 6.6$

\begin{tabular}{|c|c|c|c|c|}
\hline 1.3 & +73.9 & -1. & & \\
\hline 6.6 & 84.0 & ..... & - & 0.033 \\
\hline 10.0 & 87.4 & -..... & - & .029 \\
\hline 19.9 & 93.6 & $\ldots$ & - & .024 \\
\hline \multirow[t]{2}{*}{110.0} & 104. 3 & 6.8 & - & - \\
\hline & & & Avg.- & 0. 029 \\
\hline
\end{tabular}


TABLE 1. Mutarotation and hydrolysis measurements-Con. $0.5 \mathrm{~g}$ of L-arabinosylamine dissolved in sufficient acid, base, or buffer to give a volume of $25 \mathrm{ml}$. Solvents are listed opposite experiment numbers.

\begin{tabular}{|c|c|c|c|c|}
\hline $\begin{array}{c}\text { Time } \\
\text { (minutes) }\end{array}$ & {$[\alpha]_{D}^{20}$} & $\mathrm{pH}$ & $\begin{array}{r}\text { Mutarotation con- } \\
\text { stant, a }\end{array}$ & $\begin{array}{c}\text { Hydrolysis rate } \\
\text { constant, a } k_{\mathrm{h} \mathbf{y} \text { drol }}\end{array}$ \\
$k_{m}=\frac{1}{t_{2}-t_{1}} \log \frac{r_{t_{1}}-r_{m}}{r_{t_{2}}-r_{m}}$ & $=\frac{1}{r_{t_{1}}-r_{\infty}}$ \\
$=\frac{1}{t_{2}-t_{1}} \log \frac{r_{t_{2}}-r_{\infty}}{r_{t}}$
\end{tabular}

Experiment 12.5 volumes of $1 \mathrm{M} \mathrm{KH}_{2} \mathrm{PO}_{4}+1$ volume of $1 \mathrm{~N} \mathrm{NaOH}$ diluted to 10 volumes, $\mathrm{pH} 5.9$

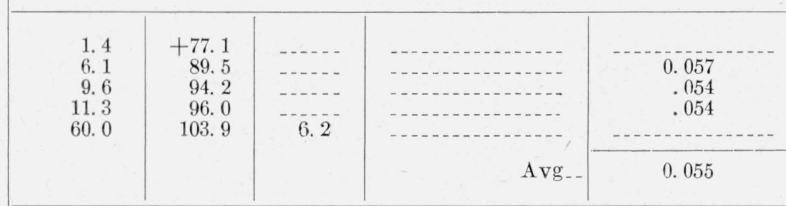

Experiment 13. 10 volumes of $1 \mathrm{M} \mathrm{KH}_{2} \mathrm{PO}_{4}+1$ volume of $1 \mathrm{~N} \mathrm{NaOH}$ diluted to 20 volumes, $\mathrm{pH} 5.5$

\begin{tabular}{|c|c|c|c|c|}
\hline \multirow{5}{*}{$\begin{array}{r}2.9 \\
5.6 \\
9.7 \\
60.0\end{array}$} & +80.1 & - & - & \\
\hline & 90.6 & - & - & 0.069 \\
\hline & 97.0 & $\ldots$ & - n & .068 \\
\hline & 104. 2 & 5.9 & - & - \\
\hline & & & A vi.- & 0.068 \\
\hline
\end{tabular}

Experiment 14.5 volumes of $1 N^{\top}$ acetic acid +3 volumes of $1 \mathrm{~N} \mathrm{NaOH}$ diluted to 10 volumes, $\mathrm{pH} 4.7$

\begin{tabular}{|c|c|c|c|c|}
\hline 1.3 & +69.4 & & & \\
\hline 9.9 & 100.1 & 5.0 & - & 0.108 \\
\hline 12.0 & 101. 6 & $\ldots .$. & - & .105 \\
\hline 13. 1 & 102.5 & -..... & - & .111 \\
\hline \multirow[t]{2}{*}{ 17. 9} & 104. 2 & - & - & - \\
\hline & & & Avg.. & 0.108 \\
\hline
\end{tabular}

Experiment 15.5 volumes of $1 \mathrm{~N}$ acetic acid +2 volumes of $1 \mathrm{~N} \mathrm{NaOH}$ diluted to 10 volumes, $\mathrm{pH} 4.4$

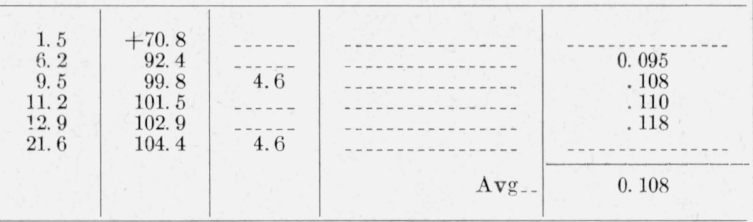

Experiment 16. 1 volume of $5.14 \mathrm{~N}$ acetic acid+1 volume of $1 \mathrm{~N} \mathrm{NaOH}$, $\mathrm{pH} 3.9$

\begin{tabular}{|c|c|c|c|c|}
\hline 2.3 & +76.0 & - & - & \\
\hline 6. 6 & 90.4 & ...... & -............. & 0.070 \\
\hline 8.2 & 93.4 & -..... & - & .069 \\
\hline 10.4 & 96.3 & 4. 0 & - & .066 \\
\hline \multirow[t]{2}{*}{41.9} & 104.7 & $\cdots+-$ & - & - \\
\hline & & & Avg & 0.068 \\
\hline
\end{tabular}

Experiment 17. 2 volumes of $5.14 \mathrm{~N}$ acetic acid +1 volume of $1 \mathrm{~N} \mathrm{NaOH}$ pH 3.5

\begin{tabular}{|c|c|c|c|c|}
\hline 1.9 & +70.7 & & r. & \\
\hline 4. 7 & 80.2 & & - n & 0.051 \\
\hline 9.7 & 90.1 & 3.6 & - & .047 \\
\hline 14.5 & 95. 3 & & - n & .044 \\
\hline \multirow[t]{2}{*}{150} & 104.8 & 3.7 & - & - \\
\hline & & & Avg & 0.047 \\
\hline
\end{tabular}

Experiment 18. 10 volumes of $5.14 \mathrm{Nacetic}$ acid +1 volume of $1 \mathrm{~N} \mathrm{NaOH}$, pH 2.7

\begin{tabular}{|c|c|c|c|c|}
\hline $\begin{array}{r}1.8 \\
2.6 \\
9.6 \\
20.0 \\
105\end{array}$ & $\begin{array}{r}+66.5 \\
68.0 \\
78.3 \\
87.6 \\
104.2\end{array}$ & 3.1 & non & $\begin{array}{r}0.022 \\
.021 \\
.021 \\
\end{array}$ \\
\hline & & & $\mathrm{Avg}_{-.}$ & 0.021 \\
\hline
\end{tabular}

TABLE 1. Mutarotation and hydrolysis measurements-Con.

$0.5 \mathrm{~g}$ of L-arabinosylamine dissolved in sufficient acid, base, or buffer to give a volume of $25 \mathrm{ml}$. Solvents are listed opposite experiment numbers.

\begin{tabular}{|c|c|c|c|c|}
\hline $\begin{array}{c}\text { Time } \\
\text { (minutes) }\end{array}$ & {$[\boldsymbol{\alpha}]_{D}^{20}$} & $\mathrm{pH}$ & $\begin{array}{l}\text { Mutarotation con- } \\
\text { stant, a } \\
k_{m}=\frac{1}{t_{2}-t_{1}} \log \frac{r_{t_{1}}-r_{m}}{r_{t_{2}}-r_{m}}\end{array}$ & $\begin{array}{l}\text { Hydrolysis rate } \\
\text { constant, a } k_{\text {hydrol }} \\
=\frac{1}{t_{2}-t_{1}} \log \frac{r_{t_{1}}-r_{\infty}}{r_{t_{2}}-r_{\infty}}\end{array}$ \\
\hline \multicolumn{5}{|c|}{ Experiment $19.1 \mathrm{~N}$ oxalic acid, $\mathrm{pH} 0.8$} \\
\hline \multirow[t]{2}{*}{$\begin{array}{r}1.4 \\
5.0 \\
480 \\
1,440 \\
1,890 \\
\infty\end{array}$} & \multirow[t]{2}{*}{$\begin{array}{r}\mathrm{e}+67.1 \\
69.3 \\
72.1 \\
77.7 \\
80.6 \\
\mathrm{~d}(105.2)\end{array}$} & \multirow[t]{2}{*}{0.8} & \multirow{2}{*}{ Avg } & $\begin{array}{c}0.000074 \\
.000081 \\
.000087\end{array}$ \\
\hline & & & & 0.000081 \\
\hline \multicolumn{5}{|c|}{ Experiment 20. $2.5 \mathrm{~N} \mathrm{HCl}$} \\
\hline \multirow[t]{2}{*}{$\begin{array}{r}3.8 \\
30.0 \\
60.0 \\
3,300 \\
35,300 \\
\infty\end{array}$} & \multirow[t]{2}{*}{$\begin{array}{r}\text { e }+69.0 \\
\text { e } 69.9 \\
70.0 \\
71.2 \\
81.2 \\
\text { d (105.2) }\end{array}$} & 0.2 & (2) & 0.0000046 \\
\hline & & & Avg... & 0.0000047 \\
\hline
\end{tabular}

a Symbols are defined in section VII, 5

b Postulated equilibrium value

- See page 144. d Postulated final value. V Value not used in calculations.

TABLE 2. Mutarotation constants of L-arabinosylamine at $20^{\circ} \mathrm{C}$

\begin{tabular}{|c|c|c|c|c|c|c|}
\hline $\begin{array}{l}\text { Expe-i- } \\
\text { ment }\end{array}$ & $\mathrm{pH}$ & {$\left[\mathrm{H}^{+}\right]$} & {$\left[\mathrm{OH}^{-}\right]$} & {$\left[\mathrm{NH}_{4}^{+}\right]$} & $k_{m}$ & $\begin{array}{l}k m \text { cor- } \\
\text { rected a }\end{array}$ \\
\hline $\begin{array}{l}1 \\
2 \\
3 \\
4 \\
5 \\
6\end{array} \ldots \ldots$ & $\begin{array}{r}12.1 \\
10.5 \\
10.5 \\
8.5 \\
8.2 \\
7.8\end{array}$ & $\begin{array}{l}\text { 7. } 94 \times 10^{-13} \\
\text { 3. } 16 \times 10^{-11} \\
\text { 3. } 16 \times 10^{-11} \\
\text { 3. } 16 \times 10^{-9} \\
\text { 6. } 31 \times 10^{-9} \\
\text { 1. } 58 \times 10^{-5}\end{array}$ & $\begin{array}{l}\text { 1. } 26 \times 10^{-2} \\
\text { 3. } 16 \times 10^{-4} \\
\text { 3. } 16 \times 10^{-4} \\
\text { 3. } 16 \times 10^{-6} \\
\text { 1. } 58 \times 10^{-6} \\
\text { 6. } 31 \times 10^{-7}\end{array}$ & $\begin{array}{l}0.1 \\
2.5 \\
0.1 \\
1.0 \\
1.0\end{array}$ & $\begin{array}{l}0.004 \\
.0015 \\
.026 \\
.022 \\
.056 \\
.117\end{array}$ & $\begin{array}{l}0.0004 \\
.0005 \\
.001 \\
.021 \\
.046 \\
.107\end{array}$ \\
\hline
\end{tabular}

a Mutarotation constant, $k_{m}$, was corrected for the catalytic effect of ammonium ion. See page 139 .

\section{Mechanisms for the Mutarotation Reac- tions of the Sugars and the Glycosylamines}

A satisfactory mechanism for the mutarotation of both the sugars and the glycosylamines must lead to an accurate expression for the rate of mutarotation as a function of the acid and base catalysts present. Years ago Hudson showed that the mutarotation constants for the sugars in the presence of strong acids and bases can be represented by the following empirical equation [6]:

$$
k_{m}=k_{\mathrm{H}_{2} \mathrm{O}}+k_{\mathrm{H}}\left[\mathrm{H}^{+}\right]+k_{\mathrm{OH}}\left[\mathrm{OH}^{-}\right],
$$

where $k_{\mathrm{H}_{2} \mathrm{O}}, k_{\mathrm{H}}$, and $k_{\mathrm{OH}}$ are constants characteristic of the particular sugar, and $\left[\mathrm{H}^{+}\right]$and $\left[\mathrm{OH}^{-}\right]$represent the concentraticns of the oxonium and hydroxyl ions, respectively. More recently it has been established that the reaction is subject to general acid and base catalysis, and consequently the expression has been extended to include terms accounting for the catalytic effect of undissociated acids, anions of weak acids and cations of weak bases [7]. Thus eq 1 is replaced by eq 2 :

$$
\begin{aligned}
& k_{m}=k_{\mathrm{H}_{2} \mathrm{O}}+k_{\mathrm{H}}\left[\mathrm{H}^{+}\right]+ \\
& k_{\mathrm{OH}}\left[\mathrm{OH}^{-}\right] \ldots+\sum^{i} k_{i}\left[\mathrm{HA}_{i}\right]+\sum^{j} k_{j}\left[\mathrm{~B}_{j}\right],
\end{aligned}
$$


in which HA signifies any hydrogen acid, neutral or ionic, and B signifies any base, neutral or ionic.

Although several mechanisms have been advanced for the mutarotation reaction, no single mechanism accounts for all of the experimental facts. To account for certain results with acid and base catalysts, including the observation [8] that the mutarotation of tetramethylglucose is negligible in either cresol or pyridine, but rapid in a mixture of the two solvents ${ }^{6}$ Lowry [10] advanced a mechanism that involves the addition of a proton at one point in the sugar molecule and simultaneous elimination of a proton at another point. The process may be represented in the following manner: ${ }^{7}$

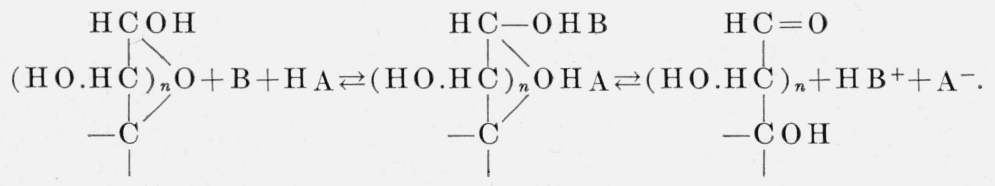

This mechanism would give rise to a third-order term in the rate expression [11], but as pointed out by Swain [12], this is not detectible because of the relative magnitude of the terms, and hence the rate constant on the basis of this mechanism can be represented within the experimental error by eq 1 . The simplicity of the mechanism makes it most attractive for interpretation of the mutarotation reaction, expecially in amphoteric solvents. Certain experimental facts, however, may be explained more satisfactorily by separate acid- and base-catalyzed mechanisms, and such mechanisms have come to be quite generally accepted. It seems probable that they act concomitantly with Lowry's mechanism, and that the extent to which each mechanism is effective is determined by the experimental conditions.

Acid-catalyzed mechanisms

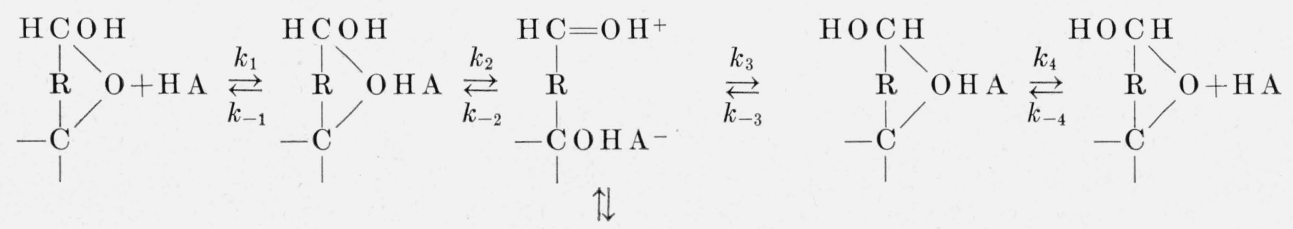

all open-chain forms

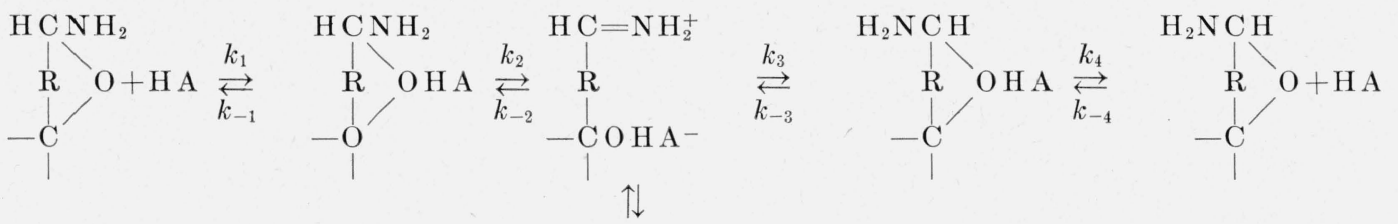

all open-chain forms

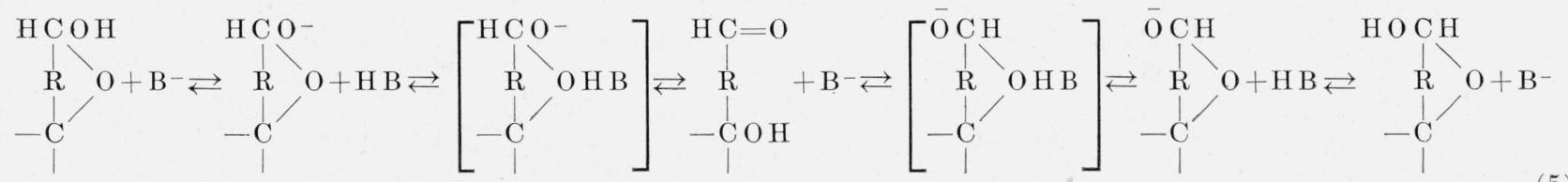

("Base-catalyzed" mechanism of [14])

${ }^{6}$ Similarly, Butler, Smith, and Stacey [9] have recently observed that the $\alpha$ - and $\beta$-tetraacetates of $N$-phenylglucosylamine are extremely stable in dry pyridine, but mutarotate to an equilibrium value on addition of a drop of water.
${ }^{7}$ Although the mechanism of eq 2 was represented in a generic fashion with respect to $H A$ and $B$, in eq 3 and succeeding mechanisms charges have been indicated for clarity. Nevertheless, the mechanisms may be regarded as generic. Thus, if $B$ in eq $6 \mathrm{a}$ is a neutral substance, then $\mathrm{HB}$ becomes $\mathrm{HB}^{+}$. 
Base-catalyzed mechanisms
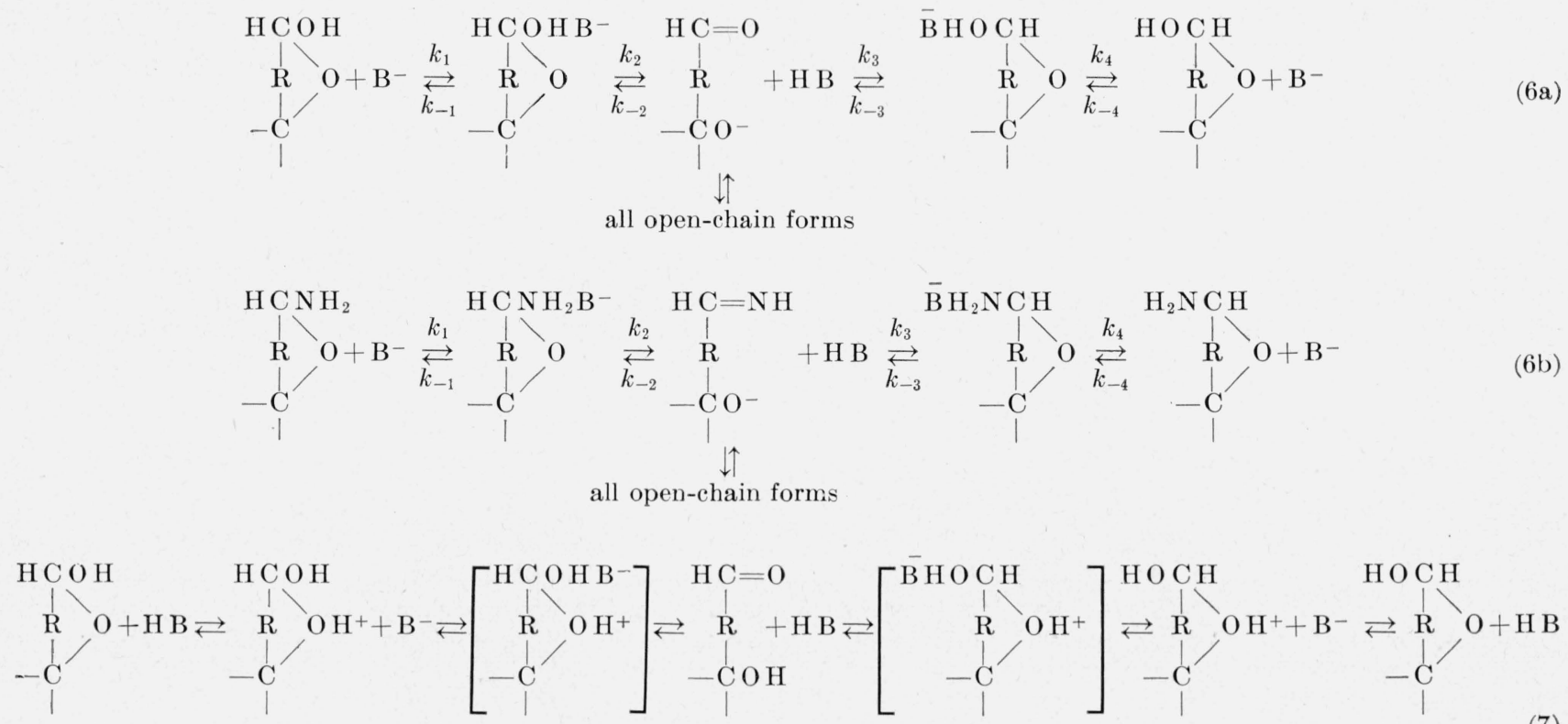

("Acid-catalyzed" mechanism of [14])

In eq 4 and 6 there are proposed acid- and basecatalyzed mechanisms that we believe represent reasonable courses for the mutarotation of the sugars and the glycosylamines. These mechanisms differ in certain respects from the mechanisms commonly accepted.

The acid-catalyzed mechanism presented here for the mutarotation of the sugars (eq 4a) begins with the addition of an acid catalyst to the ring oxygen. This is followed by rupture of the ring through as electron shift in which a lone electron pair of the glycosyl oxygen facilitates release of electrons to the ring oxygen. 'The product quickly establishes equilibrium with all species of the open-chain modification. Cyclization can then proceed through combination of carbon 1 with the oxygen of either carbon 4 or carbon 5 . This gives rise to the alpha and beta furanoses and pyranoses in equilibrium proportions.

The acid-catalyzed mutarotation of the glycosylamines is formulated in similar manner, as shown in eq $4 \mathrm{~b}$. In this case, a shift of a lone electron pair of the amino nitrogen results in the formation of the imonium ion $-\mathrm{C}=\mathrm{NH}_{2}{ }^{+}$. Reaction of carbon 1 of the imonium ion with the oxygen of carbon 4 or carbon 5 produces the various ring isomers. A mechanism of this type will account for the striking sensitivity of the mutarotation of the glycosylamines to acid catalysts.

A base-catalyzed mechanism for the mutarotation of the sugars may be represented as shown in eq $6 \mathrm{a}$. Combination of the base with the hydrogen of the glycosidic hydroxyl gives an activated complex that decomposes with separation of the conjugate base and rupture of the ring. By the reversible addition of a proton, the product establishes equilibrium with the open-chain form of the sugar. Restoration of asymmetry on carbon 1 through ring formation, facilitated by combination of the conjugate base with the carbonyl oxygen establishes equilibrium of the cyclic modifications. The glycosylamine, however, does not react to a great extent by a basecatalyzed mechanism (eq 6b) analogous to that of the free sugar because there is less tendency on the part of the amino nitrogen to release a proton.

The above mechanisms differ from those generally accepted primarily in regard to the species of the sugar undergoing reaction. According to Hammett $([13$, p. 337]) ". . . the only reasonable mechanisms are the following: for the acid catalysis the mobile and reversible addition of a proton to the ether oxygen followed by a rate-determining reaction with a base ... for the base catalysis the mobile and reversible removal of a proton, followed by a ratedetermining reaction with an acid." These mechanisms, originally advanced by Fredenhagen and Bonhoeffer [14] and based in part on the work of Bonhoeffer and Reitz [15], have been extended to the glycosylamines by Howard, Kenner, Lythgoe, and Todd [16]. The mechanisms of [14] are outlined in eq 5 and 7 , in which the steps contained in brackets have been postulated by us. Comparison shows that our acid-catalyzed mechanism of eq 4 a resembles the base-catalyzed mechanism of eq 5 , and that our basecatalyzed mechanism of eq 6 a resembles the prior acid-catalyzed mechanism of eq 7 . It will be seen that the two mechanisms classified here under acidcatalysis (eq 4a and 5), operate on different species of the sugar; this is likewise true of the two classified under base-catalysis (eq 6a and 7). The proportions 
of the species are determined by the hydrogen ion concentration and the base strength of the carbohydrate, and hence the relative importance of the several mechanisms in any solution depends on the substance and the $\mathrm{pH}$.

Presumably all of the mechanisms, in addition to Lowry's, are applicable to the sugars, with eq 5 and 6a favored in alkaline solution and $4 \mathrm{a}$ and $7 \mathrm{in}$ acid solution. It appears that eq $4 \mathrm{~b}$ would be the main course for the primary and secondary amines and indeed the only one that is applicable to tertiary amines. The mutarotation of tertiary glycosylamines was observed by Kuhn and Birkhofer [17], who concluded that the reaction involves the formation of a substituted ammonium ion followed by elimination of a proton, to give the imonium ion $-\mathrm{C}=\mathrm{NH}_{2}^{+}$.

Although eq $4 \mathrm{~b}$ involves the same imonium ion, we believe that it is produced directly from the amine rather than from the corresponding ammonium ion. It should be pointed out that the mechanism of eq 4a and $4 \mathrm{~b}$ requires only an acid catalyst and is at variance with the currently held concept that both an acid and a base catalyst are necessary for the mutarotation reaction. As applied to the alkyl glycosides, a mechanism analogous to eq $4 \mathrm{a}$ will account adequately for acid-catalyzed interconversion in nonaqueous solvents, a reaction for which mechanisms analogous to those of eq 5, 6a, and 7 are inadequate because the aglycone group does not permit attack by a base catalyst.

Apparently the acid- and base-catalyzed reactions of the sugars take place side by side, and the over-all reaction can be regarded as the sum of the parallel and competing reactions, the rates of which depend on the acid and base catalysts present. It is of interest to examine the newly postulated mechanisms to ascertain whether they will account for the effect of acid and base catalysts on the rate of mutarotation. For this purpose, the mechanisms of eq $4 \mathrm{a}$ and $6 \mathrm{a}$ can be formulated in the following manner:

Acid-catalyzed system:

$$
\begin{gathered}
\alpha+\mathrm{HA} \underset{k_{-1}}{\stackrel{k_{1}}{\rightleftarrows}} \mathrm{X}_{1} \\
\mathrm{X}_{1} \underset{k_{-2}}{\stackrel{k_{2}}{\rightleftarrows}} \mathrm{X}_{2} \\
\mathrm{X}_{2} \underset{k_{-3}}{\stackrel{k_{3}}{\rightleftarrows}} \mathrm{X}_{3} \\
\mathrm{X}_{3} \underset{k_{4}}{\rightleftarrows} \beta+\mathrm{HA} \\
k-4
\end{gathered}
$$

Base-catalyzed system:

$$
\begin{gathered}
\alpha+\mathrm{B} \underset{k-1}{\stackrel{k_{1}}{\rightleftarrows}} \mathrm{X}_{1} \\
\mathrm{X}_{1} \stackrel{k_{2}}{\rightleftarrows} \mathrm{X}_{2}+\mathrm{HB} \\
\mathrm{X}_{2}+\mathrm{HB} \underset{k_{-2}}{\stackrel{k_{3}}{\rightleftarrows} \mathrm{X}_{3}} \\
\mathrm{X}_{3} \underset{k_{-4}}{\stackrel{k_{4}}{\rightleftarrows}} \beta+\mathrm{B}
\end{gathered}
$$

In these expressions, HA represents an acid catalyst, $\mathrm{B}$ a base catalyst, $\alpha$ and $\beta$ the modifications of the sugar, and $\mathrm{X}_{1}, \mathrm{X}_{2}$, and $\mathrm{X}_{3}$ reaction intermediates. The rate constants and the intermediates are not the same for the two systems. Application of the Christiansen equations ([13, p. 107]) to the acid-and base-catalyzed systems for the sugars, and combination of rate constants, lead to the following expressions, respectively for the rates of reaction:

$$
-\frac{d[\alpha]}{d t}=\frac{d[\beta]}{d t}=k_{\mathrm{A}}[\mathrm{HA}]\left(k[\alpha]-k^{\prime}[\beta]\right),
$$

for catalysis by an acid, and

$$
-\frac{d[\alpha]}{d t}=\frac{d[\beta]}{d t}=k_{\mathrm{B}}[\mathrm{B}]\left(k[\alpha]-k^{\prime}[\beta]\right),
$$

for catalysis by a base. At equilibrium,

$$
-\frac{d[\alpha]}{d t}=0
$$

Thus $k[\alpha]-k^{\prime}[\beta]=0$ in both cases, and $k / k^{\prime}$ is fixed by the equilibrium ratio. By adjusting the arbitrary constants $k_{\mathrm{A}}$ and $k_{\mathrm{B}}$, the same value in the two equations is assigned to $k$ and likewise to $k^{\prime}$, so that $\left(k[\alpha]-k^{\prime}[\beta]\right)$ becomes a common factor for all catalysts. The over-all rate then becomes

$$
-\frac{d[\alpha]}{d t}=\left(\sum^{i} k_{i}\left[\mathrm{HA}_{i}\right]+\sum^{j} k_{j}\left[\mathrm{~B}_{j}\right]\right)\left(k[\alpha]-k^{\prime}[\beta]\right),
$$

for $i$ acid catalysts and $j$ base catalysts. If the only catalysts are oxonium ion, hydroxyl ion, and water eq 8 reduces to

$$
-\frac{d[\alpha]}{d t}=\left(k_{\mathrm{H}_{2} \mathrm{O}}+k_{\mathrm{H}}\left[\mathrm{H}^{+}\right]+k_{\mathrm{OH}}\left[\mathrm{OH}^{-}\right]\right)\left(k[\alpha]-k^{\prime}[\beta]\right),
$$

where $k_{\mathrm{H}_{2} \mathrm{O}}$ includes both acid and base catalysis by the water molecule. This equation, when integrated and expressed in terms of optical rotation by Hudson's method $[18]^{8}$ becomes

${ }^{8}$ At the time that Hudson presented his classical development of the kinetics of mutarotation, it was thought that the equilibrium of lactose was established between a ring form and an open-chain form (referred to in his article as lactone and hydrate, respectively). 
$\frac{1}{t} \ln \frac{r_{0}-r_{\infty}}{r_{t}-r_{\infty}}=\left(k_{\mathrm{H}_{2} \mathrm{O}}+k_{\mathrm{H}}\left[\mathrm{H}^{+}\right]+k_{\mathrm{OH}}\left[\mathrm{OH}^{-}\right]\right)\left(k+k^{\prime}\right)$.

By reducing to common logarithms and combining constants,

$$
\frac{1}{t} \log \frac{r_{0}-r_{\infty}}{r_{t}-r_{\infty}}=k_{\mathrm{H}_{2} \mathrm{O}}+k_{\mathrm{H}}\left[\mathrm{H}^{+}\right]+k_{\mathrm{OH}}\left[\mathrm{OH}^{-}\right]=k_{m} .
$$

This is the familiar expression that Hudson found to represent the mutarotation of glucose in acid, neutral, and alkaline solutions [6]. This derivation shows that the postulated acid-and base-catalyzed reactions are in accord with the previously known, experimentally determined relationship correlating the rate constant for the mutarotation of the sugars with the catalysts present.

The Christiansen equations may be similarly applied to the mutarotation of the glycosylamines (eq $4 \mathrm{a}$ and $4 \mathrm{~b}$ ), and the summation then takes the form:

$-\frac{d[\alpha]}{d t}=\left(\sum^{i} k_{i}\left[\mathrm{HA}_{i}\right]+\sum^{j} k_{j}\left[\mathrm{~B}_{j}\right]\right)\left(k\left[\alpha_{\mathrm{NH}_{2}}\right]-k^{\prime}\left[\beta_{\mathrm{NH}_{2}}\right]\right)$.

The expression calls for general acid and base catalysis. It has been found experimentally that the mutarotation rate is increased by the presence of ammonium, phosphate, and carbonate buffers. However, for systems in which the only catalysts are water, oxonium ion, hydroxyl ion, and ammonion ion, eq 11, when treated in the same manner as eq 8 , reduces to

$$
\begin{aligned}
\frac{1}{t} \log \frac{r_{0}-r_{\infty}}{r_{t}-r_{\infty}}=k_{\mathrm{H}_{2} \mathrm{O}}+k_{\mathrm{H}}\left[\mathrm{H}^{+}\right]+ \\
k_{\mathrm{OH}}\left[\mathrm{OH}^{-}\right]+k_{\mathrm{NH}_{4}}\left[\mathrm{NH}_{4}^{+}\right]=k_{m} .
\end{aligned}
$$

In the case of the glycosylamines, there is theoretically a complicating factor. In the derivation of the expression for the rate of mutarotation of the sugars, it is possible to assume that a direct relationship exists between the concentrations of the alpha and beta isomers and the optical rotation regardless of the presence of either more or less acid. This assumption is valid because only a minute part of the sugar exists under any given conditions in other than the normal forms. Because of the basic properties of the amino group, however, part of both the alpha and the beta glycosylamine probably exist in solution as the corresponding substituted ammonium ion. The proportion of the free amine in aqueous solutions is determined by the equilibrium:

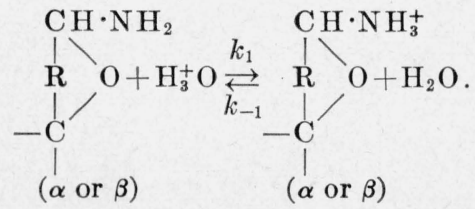

When this reaction is taken into account, it can be shown by application of the mass law that

$$
\begin{aligned}
& \frac{1}{t} \log \frac{r_{0}-r_{\infty}}{r_{t}-r_{\infty}}= \\
& \frac{k_{\mathrm{H}_{2} \mathrm{O}}+k_{\mathrm{H}}\left[\mathrm{H}^{+}\right]+k_{\mathrm{OH}}\left[\mathrm{OH}^{-}\right]+k_{\mathrm{NH}_{4}}\left[\mathrm{NH}_{4}^{+}\right]}{1+K\left[\mathrm{H}^{+}\right]}=k_{m},
\end{aligned}
$$

where $K$ is the equilibrium constant for eq 13 . Application of eq 14 to the data of table 2 gives a series of simultaneous equations that show that in the $\mathrm{pH}$ range where the mutarotation is sufficiently slow to be measurable, the effect of the term $K\left[\mathrm{H}^{+}\right]$is less than the experimental error. Consequently, the term can be neglected and eq 12 can be applied to the mutarotation of L-arabinosylamine.

From the data of table 2, numerical values were obtained for the catalytic coefficients of eq 12. At low concentrations of oxonium and ammonium ion, the quantity $k_{\mathrm{H}_{2} \mathrm{O}}+k_{\mathrm{OH}}\left[\mathrm{OH}^{-}\right]$approaches $k_{m}$, and each term must be less than the lowest observed rate $(0.0004$ at $\mathrm{pH} 12)$; hence $k_{\mathrm{H}_{2} \mathrm{O}}$ and $k_{\mathrm{OH}}$ are less than $4 \times 10^{-4}$ and $4 \times 10^{-2}$, respectively. From experiments 2 and $3, k_{\mathrm{NH}_{4}}$ was found to be $10^{-2}$. Inasmuch as $k_{\mathrm{H}_{2} \mathrm{O}}$ and $k_{\mathrm{OH}}\left[\mathrm{OH}^{-}\right]$are negligibly small in comparison with the values of $k_{m}$ in experiments 4,5 , and 6 , values of $k_{\mathrm{H}}$ were calculated on the assumption that $k_{m}=k_{\mathrm{H}}\left[\mathrm{H}^{+}\right]+10^{-2}\left[\mathrm{NH}_{4}^{+}\right]$. The average value of $k_{\mathrm{H}}$ so obtained is $6.9 \times 10^{6}$. The mutarotation constants of table 2, corrected for the catalytic effect of ammonium ion, are given in the last column of the table and are shown by the dotted curve of figure $3 .{ }^{9} \quad \mathrm{~A}$ comparison of the numerical values of the catalytic coefficients for L-arabinosylamine with those for D-glucose is given in table 3 . It may be seen that the principal catalyst for the mutarotation of D-glucose is the hydroxyl ion, whereas for the mutarotation of $\mathrm{L}$-arabinosylamine it is the oxonium ion. The striking difference arises primarily from the fact that the glycosyl oxygen has a greater tendency than the nitrogen to release a proton (eq $6 \mathrm{a}$ and $6 \mathrm{~b}$ ) and less tendency than the nitrogen to share a lone electron pair (eq $4 \mathrm{a}$ and $4 \mathrm{~b})$.

TABLE 3. Catalytic coefficients of mutarotation reactions at $20^{\circ} \mathrm{C}$

\begin{tabular}{|c|l|c|c|}
\hline Catalyst & Symbol & $\begin{array}{c}\text { L-Arabinosyl- } \\
\text { amine }\end{array}$ & D-Glucose s \\
\cline { 2 - 4 } & $k_{\mathrm{H}_{2} \mathrm{O}} \mathrm{O}$ & $<4 \times 10^{-4}$ & $2.6 \times 10^{-4}$ \\
$\mathrm{H}^{+}$ & $k_{\mathrm{H}}$ & $6.9 \times 10^{6}$ & $3.6 \times 10^{-1}$ \\
$\mathrm{OH}^{-}$ & $k_{\mathrm{OH}}$ & $4 \times 10^{-2}$ & $8 \times 10^{3}$ \\
$\mathrm{NH}_{4}^{+}$ & $k_{\mathrm{NH}_{4}}$ & $1 \times 10^{-2}$ & $1.2 \times 10^{-3}$ \\
\hline
\end{tabular}

s Data from [19]. ${ }^{9}$ In a preliminary publication [2], an expression was given to represent em-
pirically the rate of mutarotation in experiments $1,7,8$, and 9 . No attempt was pirically the rate of mutarotation in experiments $1,7,8$, and 9 . No attempters
made to evaluate the general acid and base catalysis of the buffers used. 


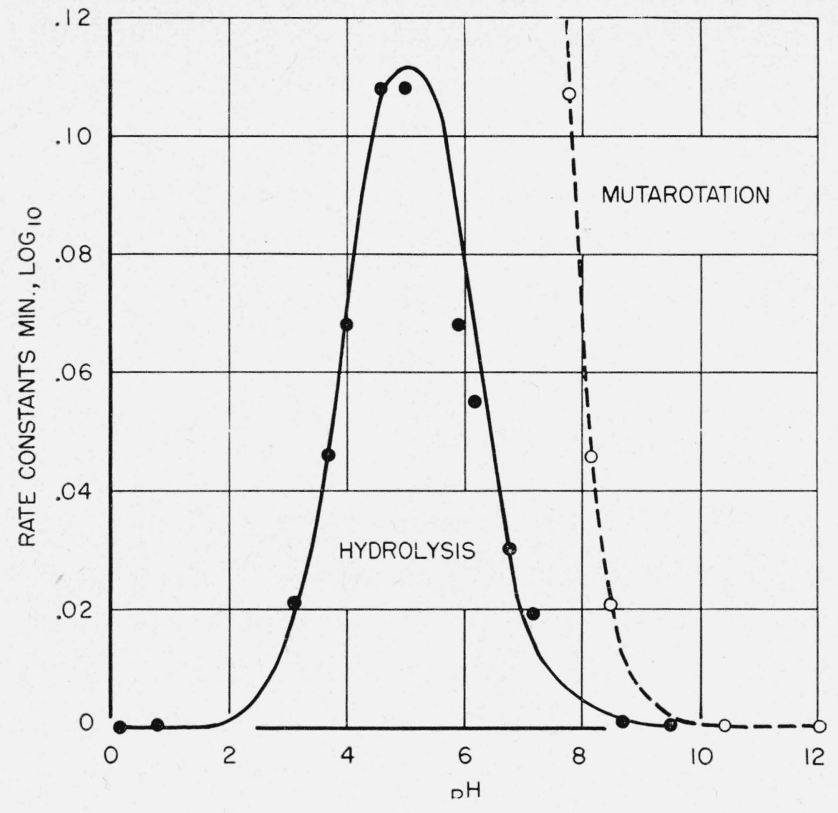

FIGURE 3. Rate constants for mutarotation and hydrolysis of L-arabinosylamine.

\section{Hydrolysis Reaction}

It has already been mentioned that the rate of hydrolysis of L-arabinosylamine was calculated from the increase in optical rotation that follows the initial decrease. The rate of hydrolysis obtained from the data of table 1 is shown in figure 3 as a function of $\mathrm{pH}$. The results bring out clearly the striking sensitivity of L-arabinosylamine to hydrolysis within a limited $\mathrm{pH}$ range. ${ }^{10}$

A satisfactory mechanism for this reaction must account for the ease of hydrolysis and the restriction of the reaction to a limited $\mathrm{pH}$ range. It follows from the well-known stability of amines to acid hydrolysis ${ }^{11}$ that the hydrolytic reaction is not characteristic of the $\mathrm{C}-\mathrm{NH}_{2}$ linkage but must be due to the glycosyl structure. It was mentioned in connection with the acid-catalyzed mutarotation that the glycosylamine is able to form the imonium ion, $-\mathrm{C}=\mathrm{NH}_{2}^{+}$, by rupture of the ring following the addition of a proton to the ring oxygen. A mechanism for hydrolysis including this substance as an intermediate is given in the next column. ${ }^{12}$ With this

10 The reaction-rate-pH curve is similar in shape to many of the enzyme activity-pH curves, among which may be cited those of urease [20], $\beta$-glucosidase [21], $\alpha$-amylase [22], and cellulase [23]. It seems possible that the sensitivity of certain enzyme systems to a change in $\mathrm{pH}$ may also arise from equilibria compacertain enzyme systems to

11 The thability of the $\mathrm{C}-\mathrm{N}$ linkage of amines is illustrated by the fact that che stability of the $-\mathrm{N}$. glucosam

acid [24]. 12 The glycosylamines are somewhat analogous to the dialkylaminomethyl alkyl ethers, which have been studied by Stewart and Bradley $[25\}$. These
authors found that the compounds are rapidly hydrolyzed by acid and explained the ease of hydrolysis by a mechanism involving the formation of an iminium ion the ease of hydrolysis by a mechanism involving the formation of an iminium ion
(imonium ion) and condensation of this with hydroxyl ion. Our mechanism includes analogous steps. structure (D), addition can take place by attachment of a nucleophilic group to the carbon, and a shift of electrons. If the nucleophilic group is hydroxyl, addition yields an intermediate aldehyde ammonia (F). This grouping is known to be unstable and gives up ammonia readily. Thus the aldehydic properties of the glycosylamine account for the facility with which ammonia is eliminated.

Proposed mechanism for the hydrolysis of glycosylamines:<smiles>[R]C(C)OC(C)C</smiles>

(B)

$\left(\mathrm{H}_{2} \mathrm{O}\right){ }_{-2 \uparrow}\left(\mathrm{H}_{3}^{+} \mathrm{O}\right)$

$\mathrm{H} \mathrm{C}=\mathrm{NH}_{2}^{+}$<smiles>[R]C(C)(C)O</smiles>

(D)

$\left(\mathrm{H}_{2} \mathrm{O}\right) k_{3}$

$\left(\mathrm{H}_{3}^{+} \stackrel{\rightleftarrows}{\mathrm{O}}\right) k_{3}$

$\left(\underset{\mathrm{H}_{2}}{\stackrel{\mathrm{O}}{\rightleftarrows}) k_{-1}^{+}}\right.$

$\left(\mathrm{H}_{3} \mathrm{O}\right) k_{3}$<smiles>[R]C(C)(C)O</smiles>

(E)<smiles>CC(C)(O)C(N)C(O)N(C(=O)O)C(C)(C)O</smiles>

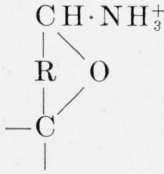

(C)
(F)

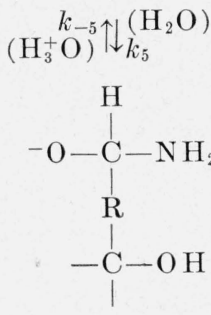

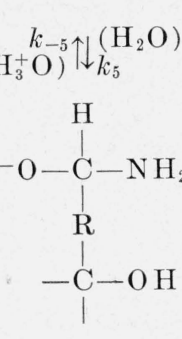

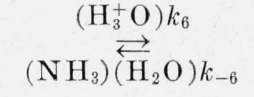

Sugar

(X)
(G)

It will be shown next that the proposed reaction mechanism will account for the fact that hydrolysis is rapid only in a limited $\mathrm{pH}$ range. Presumably the first step in the hydrolysis is the formation of the imonium ion (D) by acid catalysis; this is accompanied by a side reaction to form the glycosylammonium ion (C). The second step is the addition of a hydroxyl ion to $\mathrm{D}$, to yield the aldehyde ammonia (F); it is also accompanied by a side reaction forming 
the imine (E). The last part of the process covers the elimination of ammonia from the aldehyde ammonia. It is represented as proceeding through the ionization of $\mathrm{F}$ (reaction 5), followed by an acidcatalyzed rearrangement of the anion $(G)$ to yield the aldehyde form of the sugar, and ultimately the equilibrium mixture. The ammonia is converted to ammonium ion, thus driving the reaction to completion. In the derivation of the rate constant as a function of the oxonium ion concentration, it is postulated that in the $\mathrm{pH}$ range in which hydrolysis occurs, equilibria for all reactions except 6 are established quickly and maintained throughout the reaction. It is also assumed that within this range reaction 6 is irreversible. Inasmuch as equilibrium conditions are postulated for all reactions except 6 , the rate of hydrolysis is represented by

$$
-\frac{d(A-X)}{d t}=[\mathrm{G}]\left[\mathrm{H}^{+}\right] k_{6}
$$

where $\mathrm{A}$ is the sum of all components and $\mathrm{X}$ is the sugar formed by hydrolysis. From mass law it folows that

$$
\begin{aligned}
{[\mathrm{F}]\left[\mathrm{H}_{2} \mathrm{O}\right] k_{5} } & =[\mathrm{G}]\left[\mathrm{H}^{+}\right] k_{-5} \\
{[\mathrm{D}]\left[\mathrm{OH}^{-}\right] k_{4} } & =[\mathrm{F}] k_{-4} \\
{[\mathrm{E}]\left[\mathrm{H}^{+}\right] k_{-3} } & =[\mathrm{D}]\left[\mathrm{H}_{2} \mathrm{O}\right] k_{3} \\
{[\mathrm{~B}]\left[\mathrm{H}^{+}\right] k_{2} } & =[\mathrm{D}]\left[\mathrm{H}_{2} \mathrm{O}\right] k_{-2} \\
{[\mathrm{C}]\left[\mathrm{H}_{2} \mathrm{O}\right] k_{-1} } & =[\mathrm{B}]\left[\mathrm{H}^{+}\right] k_{1}
\end{aligned}
$$

The equations may be solved for B, C, D, E, and F in terms of $\mathrm{G}$, and the values substituted in the expression $\mathrm{A}=\mathrm{B}+\mathrm{C}+\mathrm{D}+\mathrm{E}+\mathrm{F}+\mathrm{G}+\mathrm{X}$ to obtain

$$
\begin{aligned}
(\mathrm{A}-\mathrm{X})= & {[\mathrm{G}]\left(\frac{k_{-5} k_{-4} k_{-2}}{\left[\mathrm{OH}^{-}\right] k_{5} k_{4} k_{2}}+\frac{\left[\mathrm{H}^{+}\right] k_{-5} k_{-4} k_{-2} k_{1}}{\left[\mathrm{H}_{2} \mathrm{O}\right]\left[\mathrm{OH}^{-}\right] k_{5} k_{4} k_{2} k_{-1}}+\right.} \\
& \frac{\left[\mathrm{H}^{+}\right] k_{-5} k_{-4}}{\left[\mathrm{H}_{2} \mathrm{O}\right]\left[\mathrm{OH}^{-}\right] k_{5} k_{4}}+\frac{k_{-5} k_{-4} k_{3}}{\left[\mathrm{OH}^{-}\right] k_{5} k_{4} k_{-3}}+ \\
& \left.\frac{\left[\mathrm{H}^{+}\right] k_{-5}}{\left[\mathrm{H}_{2} \mathrm{O}\right] k_{5}}+1\right) .
\end{aligned}
$$

This, when simplified by combining constants, and expressing the results in terms of new constants becomes

$$
[\mathrm{G}]=\frac{(\mathrm{A}-\mathrm{X})\left[\mathrm{OH}^{-}\right]^{2}}{\left[\mathrm{OH}^{-}\right]^{2}+k^{\prime}\left[\mathrm{OH}^{-}\right]+k^{\prime \prime}} .
$$

If the derived value for $[\mathrm{G}]$ is substituted in eq 15 , it becomes

$$
-\frac{d(\mathrm{~A}-\mathrm{X})}{d t}=\frac{(\mathrm{A}-\mathrm{X})\left[\mathrm{OH}^{-}\right]^{2}\left[\mathrm{H}^{+}\right] k_{6}}{\left[\mathrm{OH}^{-}\right]^{2}+k^{\prime}\left[\mathrm{OH}^{-}\right]+k^{\prime \prime}}
$$

which may be simplified by multiplying numerator and denominator by $\left[\mathrm{H}^{+}\right]$, and combining constants to obtain

$$
-\frac{d(\mathrm{~A}-\mathrm{X})}{d t}=\frac{(\mathrm{A}-\mathrm{X})}{\mathrm{K}^{\prime}+\mathrm{K}^{\prime \prime}\left[\mathrm{H}^{+}\right]+\mathrm{K}^{\prime \prime \prime}\left[\mathrm{OH}^{-}\right]} .
$$

After integration, evaluation of the integration constant and conversion to common logarithms, the equation becomes

$$
\frac{1}{t} \log \frac{\mathrm{A}}{(\mathrm{A}-\mathrm{X})}=\frac{1}{\mathrm{~K}_{1}+\mathrm{K}_{2}\left[\mathrm{H}^{+}\right]+\mathrm{K}_{3}\left[\mathrm{OH}^{-}\right]}=k_{\text {hydrol }},
$$

where $k_{\text {hydrol }}$ is the hydrolysis rate constant. Inasmuch as the change in optical rotation during the hydrolysis period is a measure of the change in $(\mathrm{A}-\mathrm{X})$, the expression in terms of optical rotation becomes

$$
\frac{1}{t_{2}-t_{1}} \log \frac{r_{t_{1}}-r_{\infty}}{r_{t_{2}}-r_{\infty}}=\frac{1}{\mathbf{K}_{1}+\mathrm{K}_{2}\left[\mathrm{H}^{+}\right]+\mathrm{K}_{3}\left[\mathrm{OH}^{--}\right]}=k_{\text {hydrol }} \cdot
$$

By use of the data of table 4, nine simultaneous equations corresponding to eq 16 were set up. Combination of these in groups of 4,2, and 3, and solution by the method of averages gave values of $7.9,6.1 \times 10^{4}$ and $4.2 \times 10^{8}$, respectively, for $\mathrm{K}_{1}, \mathrm{~K}_{2}$, and $\mathrm{K}_{3}$. Thus,

$$
k_{\text {hydrol }}=\frac{1}{7.9+6.1 \times 10^{4}\left[\mathrm{H}^{+}\right]+4.2 \times 10^{8}\left[\mathrm{OH}^{-}\right]} .
$$

A piot of this expression is shown by the solid curve of figure 3 ; the experimental results are in good agreement with the curve. Thus, the postulated mechanism and the equation developed from kinetic considerations account for the fact that hydrolysis is rapid only in a limited $\mathrm{pH}$ range.

TABLE 4. Summary of data for the hydrolysis reaction at $20^{\circ} \mathrm{C}$

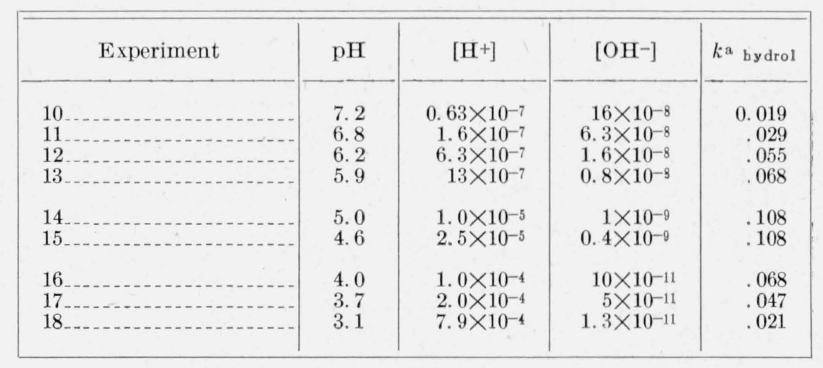

a $k_{\text {bydrol }}=1 /\left(t_{2}-t_{1}\right) \log \left(r_{t_{1}}-r_{\infty}\right) /\left(r_{t_{2}}-r_{\infty}\right)$, where $r_{t_{1}}$ is the first measurement. in the period used for evaluating the rate of hydrolysis.

In the preceding discussion, it was necessary to omit consideration of the individual reaction constants and of catalysis by acids and bases other than oxonium and hydroxyl ions. ${ }^{13}$ Furthermore, it was not possible to consider the several ring isomers of the system separately. In the mechanism on page 140 , intramolecular reaction of carbon 1

${ }^{13}$ Inasmuch as equilibrium conditions prevail during the hydrolysis, general catalysis in the formation of the imonium ion does not affect the rate of hydrolysis, although it accelerates the rate of mutarotation. 
of $\mathrm{D}$ with the hydroxyl of carbon 4 would give the alpha and beta furanosylamines; reaction with the hydroxyl of carbon 5 would give the alpha and beta pyranosylamines. Hence $\mathrm{B}$ and $\mathrm{C}$ symbolize all cyclic modifications of the glycosylamine, and the corresponding cation, respectively, and the constants of reactions 1 and 2 represent composite rates. Similarly, F includes both stereomeric modifications of carbon 1, and the constants of reaction 5 represent composite rates.

\section{Evidence for the Formation of an Un- known Product, Possibly the Digly- cosylamine}

In some cases the mutarotation and hydrolysis appear to be complicated further by a side reaction that takes place during the early part of the reaction period and varies in importance with the experimental conditions. Evidence of this complicating factor may be seen from the data of table 5. It will be observed that when an excess of acid is added slowly to L-arabinosylamine, the optical rotation drops to a lower point than when the acid is added quickly. The product having the lower rotation appears to be hydrolyzed more rapidly than the other, as the optical rotation of the solution rises more rapidly and ultimately exceeds that of the solution containing less of the byproduct. It seems probable that the complication is caused by the formation of a diarabinosylamine. Evidence of this reaction is also found in experiments 19 and 20 of table 1 . In these, the initial observed rotation is lower than usual, and the early change in optical rotation is too rapid to be due entirely to the hydrolysis of L-arabinosylamine. As the reaction, after the first few minutes, appears to follow the first-order course, the calculations of the rate were made without the use of the early anomalous values. In experiment 18 of table 1, however, although the initial rotation is likewise low, the entire mutarotation follows the first-order course. The side reaction, which under other conditions may become of major importance, is being studied further.

TABLE 5. Reaction of L-arabinosylamine with acid (evidence for a side reaction)

$0.25 \mathrm{~g}$ of L-arabinosylamine dissolved in sufficient $2.5 \mathrm{~N} \mathrm{HCl}$ to give a volume of $25 \mathrm{ml}$

\begin{tabular}{|c|c|c|}
\hline $\begin{array}{c}\text { Time after begin- } \\
\text { ning the addi- } \\
\text { tion of acid }\end{array}$ & $\begin{array}{c}\text { Optical rota- } \\
\text { tion after rapid } \\
\text { addition of } \\
\text { acid }\end{array}$ & $\begin{array}{c}\text { Optical rota- } \\
\text { tion after drop- } \\
\text { wise addition } \\
\text { of acid during } \\
2.5 \text { minutes }\end{array}$ \\
\cline { 1 - 2 } Minutes & {$[\alpha]_{D}^{20}$} & {$[\alpha]_{D}^{20}$} \\
3.8 & 69.0 & 67.2 \\
7.0 & 69.3 & 68.2 \\
15.0 & 69.7 & 69.4 \\
30.0 & 69.9 & 70.5 \\
60.0 & 70.0 & 71.0 \\
Change in $[\alpha]_{D}^{20}$ & & \\
in 1 hr. -... & 1.0 & 3.8 \\
\hline
\end{tabular}

\section{Role of the Imonium Ion in Other Reactions of Glycosylamines}

It is believed that the imonium ion, considered to be an intermediate in the hydrolysis reaction, accounts not only for the formation of the diglycosylamine but for several other reactions. Thus the addition of a nucleophilic substance, as for instance a cyanide ion, would take place most readily through the imonium ion, and the concentration of this cation would largely determine the reaction rate. The imonium ion also plays a part in reactions of the Amadori type; mechanisms for some of these were presented in a prior publication [26].

\section{Experimental Details}

\section{L-Arabinosylamine}

Dry ammonia was passed slowly, at room temperature, into $100 \mathrm{ml}$ of methanol containing $1 \mathrm{~g}$ of ammonium chloride and $20 \mathrm{~g}$ of L-arabinose in suspension. Addition of ammonia was discontinued when the sugar had entirely gone into solution. Ether was then added to the point of incipient turbidity, and the mixture was allowed to stand in the refrigerator until crystallization of L-arabinosylamine occurred (3 weeks). The crystals were collected on a filter, washed with methanol, and air-dried; the yield was $15 \mathrm{~g}$. Recrystallization was conducted by dissolving the crude arabinosylamine in $30 \mathrm{ml}$ of a 1:10 mixture of concentrated ammonia and water. The solution was filtered and diluted with $60 \mathrm{ml}$ of methanol saturated with ammonia, and then with $150 \mathrm{ml}$ of absolute ethanol. The resulting crystals were separated after 2 hours, washed with methanol saturated with ammonia, and dried at room temperature in a vacuum desiccator containing phosphoric anhydride. The recrystallized product weighed $10.8 \mathrm{~g}$, and melted at $124^{\circ} \mathrm{C}$. At a concentration of $2 \mathrm{~g} / 100 \mathrm{ml}$ in $\mathrm{CO}_{2}$-free water, $[\alpha]_{D}^{20}=+86.3^{\circ}(5 \mathrm{~min})$; $83.8^{\circ}(60 \mathrm{~min}): 78.6^{\circ}(7 \mathrm{hr}) ; 80.5^{\circ}(54 \mathrm{hr})$. De Bruyn and Van Leent [2], who first prepared the compound, reported mp $124^{\circ} \mathrm{C}$ and $[\alpha]_{D}^{20}+83^{\circ}$ $\left(\mathrm{H}_{2} \mathrm{O}, c=10\right)$.

Figure 1 shows the titration curve obtained when $0.1 \stackrel{N}{N C l}$ was added portionwise to $75 \mathrm{ml}$ of a solution containing $0.1493 \mathrm{~g}$ of L-arabinosylamine. Sufficient time was allowed after each addition of acid for the $\mathrm{pH}$ of the solution to reach equilibrium. At the end of the experiment, the optical rotation corresponded to that of L-arabinose, and after the ammonium chloride and excess acid were removed by treatment with ion-exchange resins, $0.14 \mathrm{~g}$ of crystalline arabinose was obtained from the solution. This is a nearly quantitative yield.

\section{Tetraacetyl-L-Ārabinosylamine}

A mixture of $4 \mathrm{~g}$ of finely powdered L-arabinosylamine, $40 \mathrm{ml}$ of pyridine and $16 \mathrm{ml}$ of acetic anhydride, in a flask equipped with a mechanical stirrer, was 
kept in an ice bath and stirred until solution was complete $(4 \mathrm{hrs})$. After 18 hours at $0^{\circ} \mathrm{C}$, the solution was poured into a mixture of ice and water, and the product was extracted with chloroform. Evaporation of the chloroform gave a crystalline residue that was recrystallized from hot ethanol. The yield was $3.65 \mathrm{~g}$. After several recrystallizations, tetraacetyl-L-arabinosylamine melted at $177^{\circ}$ to $178^{\circ} \mathrm{C} ;[\alpha]_{D}^{20}=+89.6^{\circ}\left(\mathrm{CHCl}_{3}, c=1.6\right)$.

Analysis: Calculated for $\mathrm{C}_{13} \mathrm{H}_{19} \mathrm{O}_{8} \mathrm{~N}$ : C, $49.21 ; \mathrm{H}$, $6.04 ; \mathrm{N}, 4.41 ; \mathrm{CO} \cdot \mathrm{CH}_{3}, 54.26$. Found: $\mathrm{C}, 49.3$; $\mathrm{H}, 6.1 ; \mathrm{N}, 4.4 ; \mathrm{CO} \cdot \mathrm{CH}_{3}, 52.4$.

\section{N-Acetyl-L-Arabinosylamine}

Six grams of tetraacetyl-L-arabinosylamine was dissolved in $100 \mathrm{ml}$ of anhydrous methanol, and 10 $\mathrm{ml}$ of $0.1 N$ barium methylate in methanol was added. The alcohol was removed by distillation under reduced pressure, with exclusion of moisture. The residue was dissolved in water and treated successively with a cation and an anion exchange resin to remove barium salts. The resulting solution, after evaporation, gave $3.6 \mathrm{~g}$ of crystalline product. To recrystallize, the material was dissolved in $6 \mathrm{ml}$ of hot water, and the solution was treated with a decolorizing carbon. After filtration, the solution, combined with $2 \mathrm{ml}$ of washings, was diluted with 2 volumes of methanol, and the mixture was allowed to stand for several hours at $0^{\circ} \mathrm{C}$. The crystalline $N$-acetylarabinosylamine was separated and washed with methanol. Melting point, $222^{\circ}$ to $224^{\circ} \mathrm{C} ;\lceil\alpha]_{D}^{20}=+69.1^{\circ}\left(\mathrm{H}_{2} \mathrm{O}, c=4\right)$. The constants were unchanged after further crystallization.

Analysis: Calculated for $\mathrm{C}_{7} \mathrm{H}_{13} \mathrm{O}_{5} \mathrm{~N}$ : C, 43.97; H, 6.85 ; N, 7.33. Found: C, 44.1; H, 6.8; N, 7.4.

\section{Periodate Oxidation of $N$-Acetyl-L- Arabinosylamine}

It was found that the optical rotation of a solution that was $0.1 M$ with respect to $N$-acetyl-L-arabinosylamine and $0.25 \mathrm{M}$ with respect to sodium metaperiodate $\left(\mathrm{NaIO}_{4}\right)$ quickly changed from a dextro to a levo direction and attained a maximum $\left([\alpha]_{D}^{20}=-49^{\circ}\right)$ in 14 minutes. After this time, there was a very gradual decrease in levo-rotation. At intervals, $10-\mathrm{ml}$ aliquots of the solution were withdrawn, and each sample was treated with $10 \mathrm{ml}$ of a saturated solution of sodium bicarbonate, $25 \mathrm{ml}$ of $0.1 \mathrm{~N}$ sodium arsenite, and $1 \mathrm{ml}$ of a 20-percent solution of potassium iodide. The excess arsenite was then titrated with a $0.1 N$ solution of iodine. The values in table 6 show that two moles of periodate were consumed per mole of glycosylamine in 10 minutes, and that further consumption of periodate was negligible. These results are in harmony with a pyranoside structure for $N$-acetyl-L-arabinosylamine. The change in optical rotation that takes place during the oxidation is also given in table 6 . The levorotatory product, presumably

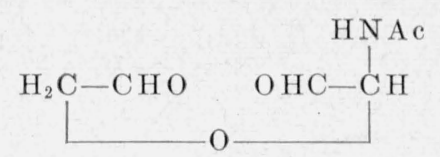

is characteristic of all $N$-acetyl-pentapyranosylamines having the same configuration for carbon 1 as that of $N$-acetyl-L-arabinosylamine.

TABLE 6. Oxidation of N-acetyl-L-arabinosylamine with sodium metaperiodate

\begin{tabular}{|c|c|c|}
\hline $\begin{array}{l}\text { Reaction } \\
\text { time }\end{array}$ & $\begin{array}{c}\text { Optical ro- } \\
\text { tation a }\end{array}$ & $\begin{array}{l}\text { Moles peri- } \\
\text { odate per } \\
\text { mole amine }\end{array}$ \\
\hline $\begin{array}{c}\text { Minutes } \\
2.5 \\
3.4 \\
5.0 \\
5.3 \\
7.3\end{array}$ & $\begin{array}{c}{[\alpha]_{D}^{20}} \\
+19.6 \\
-6.9 \\
-30.9 \\
-42.8\end{array}$ & 1.92 \\
\hline $\begin{array}{c}10.0 \\
10.7 \\
14.2 \\
30 \\
60 \\
120\end{array}$ & $\begin{array}{l}-47.4 \\
-49.0 \\
-44.8\end{array}$ & $\begin{array}{c}1.99 \\
2.00 \\
2.01\end{array}$ \\
\hline
\end{tabular}

a Based on weight of $\mathrm{N}$-acetyl-L-arabinosylamine.

\section{Mutarotation and Hydrolysis Measurements}

The course of the mutarotation and hydrolysis reactions was followed by measurements of optical rotation on solutions of L-arabinosylamine containing known amounts of acids and bases. In each experiment, $0.5 \mathrm{~g}$ of crystalline L-arabinosylamine was placed in a 25 -ml volumetric flask. Sufficient acid, base, or buffer solution at $20^{\circ} \mathrm{C}$ was added rapidly to give a volume of $25 \mathrm{ml}$, and measurements were made of the optical rotation in a $4-\mathrm{dm}$ tube. Time was measured from the moment the solvent was added to the crystals. At the end of the experiment, and in some cases at intermediate points, the $\mathrm{pH}$ of the reaction mixture was measured. As 1 mole of ammonia is liberated during the hydrolysis, it was not possible to maintain the hydrogen ion concentration constant, and in each case the $\mathrm{pH}$ of the solution increased somewhat as the reaction proceeded. For purpose of comparison, the values obtained at the end of the experiment were used in the calculations.

In solutions more acid than $\mathrm{pH} 7.8$, the initial decrease in optical rotation that characterizes the mutarotation was too rapid to detect. In the $\mathrm{pH}$ range 7.8 to 12 , velocity constants for the mutarotation were calculated by the formula

$$
k_{m}=\frac{1}{t_{2}-t_{1}} \log \frac{r_{t_{1}}-r_{m}}{r_{t_{2}}-r_{m}}
$$

where $r_{t_{1}}$ and $r_{t_{2}}$ are the specific rotations at times $t_{1}$ and $t_{2}$, and $r_{m}$, the minimum optical rotation, is assumed to be the equilibrium rotation in the absence of hydrolysis. In some experiments the minimum rotation was not reached because the 
reaction either was too slow, or was complicated by competitive hydrolysis. In these cases, a value of $+69^{\circ}$, the minimum rotation found for uncomplicated cases, was used for $r_{m}$.

It is noteworthy that the equilibrium rotation obtained in highly alkaline solution in the presence of $2.5 \mathrm{~N}$ ammonium chloride (experiment 3, table 1 ), is appreciably lower than that found at the same $\mathrm{pH}$ in the presence of only $0.1 \mathrm{~N}$ ammonium chloride (experiment 2). The cause of the difference is not known, but it may be due to the side reaction mentioned on page 142 .

The rate of hydrolysis was calculated from the rise in optical rotation that takes place after the primary mutarotation reaction is complete. In the calculations it is assumed that the second change in rotation is due solely to the hydrolysis reaction and that the optical rotations of both the arabinosylamine and the product, L-arabinose, remain constant throughout the period chosen for the rate measurement.

The values for the hydrolysis rate constant given in table 1 were calculated from the formula

$$
k_{\text {hydrol }}=\frac{1}{t_{2}-t_{1}} \log \frac{r_{t_{1}}-r_{\infty}}{r_{t_{2}}-r_{\infty}}
$$

where $r_{t_{1}}$ and $r_{t_{2}}$ are the rotations at times $t_{1}$ and $t_{2}$, respectively, and $r_{\infty}$ is the specific rotation of the fully hydrolyzed material.

\section{Summary}

It has been found that L-arabinosylamine undergoes a mutarotation reaction that is followed or accompanied by hydrolysis of the amino group. The mutarotation takes place at measurable rates between $\mathrm{pH} 7.8$ and 12, but it is too rapid to observe in solutions of higher oxonium ion concentrations. Mechanisms are proposed for the mutarotations of the glycosylamines and of the sugars. The mutarotation of the glycosylamines, in marked contrast to that of the sugars, is not appreciably catalyzed by hydroxyl ion, but is strongly catalyzed by oxonium ion. Apparently mutarotation and hydrolysis of the glycosylamines take place through an intermediate imonium ion.

The rate of hydrolysis of L-arabinosylamine is unusually sensitive to the acidity of the medium, is greatest at $\mathrm{pH} 5$, and is negligible in both alkaline and highly acid solutions. A mechanism is proposed to account for these facts and by application of mass law to the reaction scheme and evaluation of the constants, the following expression is obtained for the rate of hydrolysis:

$$
k_{\mathrm{hydrol}}=\frac{1}{7.9+6.1 \times 10^{4}\left[\mathrm{H}^{+}\right]+4.2 \times 10^{8}\left[\mathrm{OH}^{-}\right]} .
$$

To provide information concerning the structure of L-arabinosylamine, the following new compounds were prepared: Tetraacetyl-L-arabinosylamine $\left(\mathrm{C}_{13} \mathrm{H}_{19} \mathrm{O}_{8} \mathrm{~N}\right)$, mp $177^{\circ}$ to $178^{\circ} \mathrm{C},[\alpha]_{D}^{20}=+89.6^{\circ}$ $\left(\mathrm{CHCl}_{3} . \quad c=1.6\right) ; \quad N$-acetyl-L-arabinosylamine $\left(\mathrm{C}_{7}\right.$ $\left.\mathrm{H}_{13} \mathrm{O}_{5} \mathrm{~N}\right)$, mp $222^{\circ}$ to $224^{\circ} \mathrm{C},[\alpha]_{D}^{20}=+69.1^{\circ}\left(\mathrm{H}_{2} \mathrm{O}\right.$, $c=4)$. The latter substance was found to react quickly with 2 moles of sodium periodate, as required for an $\mathrm{N}$-acetylpentosylamine having the pyranose structure.

The authors gratefully acknowledge the assistance of Nancy B. Holt in various phases of the work, and of Rolf A. Paulson, who analyzed the compounds reported. They also express their appreciation to T. D. Stewart of the University of California for kindly and helpful criticism of the reaction mechanisms.

\section{References}

[1] H. L. Frush and H. S. Isbell, J. Research NBS 41, 609 (1948) RP1943.

[2] H. S. Isbell and H. L. Frush, J. Am. Chem. Soc. 72, 1043 (1950).

[3] C. A. Lobry de Bruyn and F. H. Van Leent, Rec. trav. chim. Pays-Bas. 14, 129 (1895).

[4] P. Brigl and H. Keppler, Z. physiol. Chem. 180, 38 (1929).

[5] C. Niemann and J. T. Hays, J. Am. Chem. Soc. 62, 2960 (1940).

[6] C. S. Hudson, J. Am. Chem. Soc. 29, 1571 (1907).

[7] J. N. Brönsted and E. A. Guggenheim, J. Am. Chem. Soc. 49, 2554 (1927).

[8] T. M. Lowry and I. J. Faulkner, J. Chem. Soc. 127, $2883(1925)$.

[9] K. Butler, F. Smith, and M. Stacey, J. Chem. Soc. 1949, 3371.

[10] T. M. Lowry, J. Chem. Soc. 127, 1371 (1925).

[11] G. E. K. Branch and M. Calvin, Theory of organic chemistry, p. 404 (Prentice-Hall, Inc., New York, N. Y., 1944).

[12] C. G. Swain, Abstracts of papers, p. 47P (116th Meeting, Am. Chem. Soc., Atlantic City, N. J., Sept. 21, 1949).

[13] L. P. Hammett, Physical organic chemistry (McGrawHill Book Co., Inc., New York, N. Y., 1940).

[14] H. Fredenhagen and K. F. Bonhoeffer, Z. physik. Chem. [A] 181, 392 (1938).

[15] K. F. Bonhoeffer and O. Reitz, Z. physik. Chem. [A] 179, 135 (1937).

[16] G. A. Howard, G. W. Kenner, B. Lythgoe, and A. R. Todd, J. Chem. Soc. 1946, 855.

[17] R. Kuhn and L. Birkofer, Ber. deut. chem. Ges. 71 , 1535 (1938).

[18] C. S. Hudson, Z. physik. Chem. 44, 487 (1903).

[19] T. M. Lowry and G. F. Smith, Rapports sur les hydrates de carbone, p. 116, 10th Conference of the International Union of Chemistry (Liege, 1930).

[20] S. F. Howell and J. B. Sumner, J. Biol. Chem. 104, 619 (1934).

[21] K. Hill, Ber. Verhandl. sächs Akad. Wiss. Leipzig, Math. phys. Klasse. 86, 115 (1934). See also, W. W' Pigman and R. M. Goepp, Jr., Carbohydrate chemistry, p. 490 (Academic Press, New York, N. Y., 1948).

[22] E. Ohlsson, Z. physiol. Chem. 189, 17 (1930).

[23] G. A. Greathouse, Textile Research J. 20, 227 (1950).

[24] C. S. Hudson and J. K. Dale, J. Am. Chem. Soc. 38, 1431 (1916).

[25] T. D. Stewart and W. E. Bradley, J. Am. Chem. Soc. 54, 4172 (1932).

[26] H. S. Isbell, Ann. Rev. Biochem. 12, 206 (1943).

Washington, July 25, 1950 